\title{
A CLINICAL EVALUATION OF LEVOMEPROMAZINE IN ANAESTHESIA ${ }^{1}$
}

\section{A Romagnoli, M.D., M Cohen, M D, and M J Diamond, M.B., Ch.B. ${ }^{2}$}

SigWALD AND CO-WORKERS (1) reported in 1956 on a new phenothiazine derivative prepared by the Rhône-Poulenc Research Laboratories: R.P. 7044 or levomepromazme, 1-methoxy-3-(dimethylamino-3'-methyl-2'-propyl)-10-phenothiazine acid maleate. ${ }^{3}$

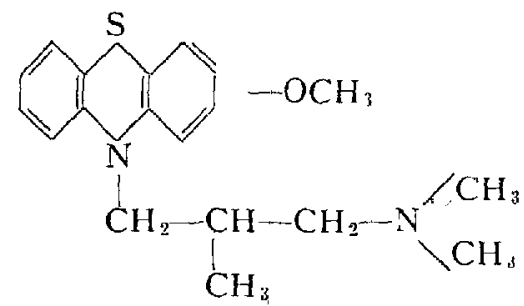<smiles>O=C(O)C=CC(C(=O)O)C(=O)O</smiles>

It is a white powder, sparmgly soluble in water and ethanol; its molecular weight is 444.5 The $\mathrm{pH}$ of a saturated aqueous solution is between 30 and 5.0. The acute toxicity was found similar to that of chlorpromazine (2). Experiments on chronic toxicity demonstrated that a dose of $10 \mathrm{mg} . / \mathrm{kg}$./day caused no histological changes in the rat. In the dog $5 \mathrm{mg} / \mathrm{kg}$. daily brought about hypomyotonia and hypotension, splemic haematoṕoietic block, and hepatic parenchymal congestion: all these changes were slowly reversible. R.P. 7044 was demonstrated to be adrenolytic, sympatholytıc, and weakly parasympatholytic. It is a very potent antihıstaminic, ant1-emetic, antishock, spasmolytıc, and has a depressıve psychomotor effect 75 per cent greater than chlorpromazine. Finally levomepromazine potentiates narcosis considerably, but its potentiating action on analgesia is not as great Courvoisier et al. (3) extended the experimental studies on R.P. 7044 and fundamentally confirmed the previous results. Faure et al. (4) used it successfully on children under the age of thirteen years, while other authors $(5,6,7)$ tried it on patients of all ages in good as well as poor general condition affected by a large variety of psychiatric and neurological disorders Never did they encounter dangerous reactions, on the contrary, their results in this field of medicine were most encouráging

In view of the qualities manitested by levomepromazine, we decided to use this drug in a trial series of anaesthetics for surgical operations. The patients were not selected, but strong young male adults were avoided in our series, because neuroplegic drugs act poorly on this type of subject. The drug was only administered intravenously in the operating room to produce or to supplement anaesthesia. None of our patients was ambulatory. Children were also excluded from our series merely because of the technical difficulty involved in convincing our young patients to willingly undergo an intravenous injection. We

'Supported by Poulenc Limited, Montreal.

2Department of Anesthesia, Jewish General Hospital, Montreal.

3Trade name, Nozinan, Poulenc Limited 
varied the inital dose of the drug under study according to the condition of the patient, the type of operation, and the operator. The final result was gauged so as to obtain the same smooth and uneventful anaesthesia, thus cancelling all other factors. A total of one hundred and fifty patients were given the drug in this series. The surgical operations during which R.P. 7044 was adminstered were:

\begin{tabular}{lr} 
Gastrectomies & 6 \\
Cholecystectomies & 15 \\
Bowel resections & 19 \\
Hysterectomies & 17 \\
Hernias & 11 \\
Mastectomies & 10 \\
Prostatectomies & 22 \\
Vagnal repars & 10 \\
Orthopaedic operations & 9 \\
E N T and neck operations & 13 \\
Plastic operations & 7 \\
Endoscopies & 11 \\
\multicolumn{1}{c}{ ToTaL } & 150
\end{tabular}

Levomepromazne was associated during its administration with several other drugs in everyday use by the anaesthetist; the results showed that there was no contraindication whatsoever to this mixing of drugs.

TABLE I

Types of ANaEsthetics With WHICH R P 7044 WAS ADMinistered

\begin{tabular}{|c|c|c|c|c|}
\hline Group & Induction & Masr & ritenance & \\
\hline \multirow[t]{3}{*}{$A$} & Thıopentone & Nitrous oxide & & 48 \\
\hline & & & $\bar{c}$ Succinylcholine & 27 \\
\hline & & & $\bar{c}$ Curare & 10 \\
\hline \multirow[t]{3}{*}{$\mathrm{B}$} & Thiopentone & Nitrous oxide & Fluothane & 18 \\
\hline & & & $\bar{c}$ Succinylcholine & 19 \\
\hline & & & Curare & 12 \\
\hline $\mathrm{C}$ & Thiopentone & Cyclopropane & & 4 \\
\hline $\mathrm{D}$ & Nitrous oxide & Nitrous oxide & & 4 \\
\hline $\mathrm{E}$ & Spinal anaesthesia & & & 8 \\
\hline
\end{tabular}

The patient response to curarizing agents, bcth of the competitive and depolarizing type was unchanged, and no difference could be noted from the response of patients to whom R.P. 7044 had not been given.

The results obtained from this series of cases were indeed most encouraging. Assessment of the results was done as follows: results were judged poor, satisfactory, or good, according to the nature of the anaesthetic induction, the maintenance, the operative condition, and the recovery, and in relation to the presence of side effects. A result was considered poor when there were complaints and unbalanced anaesthesia and when the technique had to be abandoned. In a satisfactory result the final outcome was good with the patient doing well throughout, even though the anaesthesia was slightly unsettled at times. Finally, for a good result everything went well at all times. 
TABLE II

\begin{tabular}{lrrrrr}
\multicolumn{5}{c}{ Classification of } & Results \\
\hline \hline Groups & $A$ & $B$ & $C$ & $D$ & $E$ \\
\hline Good & 71 & 47 & 4 & 4 & 8 \\
Satisfactory & 10 & 2 & & & \\
Poor. & 4 & & & & \\
\hline
\end{tabular}

The four poor results recorded belong to Group A (Table I), where thiopentonenitrous oxide only were administered together with the drug under study; in these four cases, the patients reacted to pannful stimuli by coughing and moving so much that the technique had to be abandoned. One of these was also complicated by hypotension. This was a 59-year-old white female patient in good general condition, undergoing a vaginal hysterectomy and anterior and posterior colporrhaphy: B.P. $140 / 80$, pulse $75 / \mathrm{mm}, \mathrm{Hb} .75$ per cent, heart and lungs normal The anaesthetic was never well under control and during the $150 \mathrm{~min}$. that the procedure lasted the patient often reacted to pain by moving and by coughing. Only $15 \mathrm{mg}$. of levomepromazine could be given beeause of a steadily dropping blood pressure $(70 / 50 \mathrm{~mm} \mathrm{Hg})$ which responded well and permanently to Vasoxyl $10 \mathrm{mg}$. intravenously and $5 \mathrm{mg}$ intramuscularly $10 \mathrm{~min}$. later. The patient had all the laryngeal and pharyngeal reflexes within 10 min. of the end of the operative procedure, while the blood pressure was stabilized at 110/70 mm.Hg. The patient made an uneventful recovery.

The time which elapsed between the return to the ward and the first administration of analgesic was carefully recorded in our series. It was compared with a similar number of cases where Leyomepromazine was not given because it was noticed from the beginning that the difference was considerable and of clinical significance.

The average-time free from pain for the 150 patients who received R.P. 7044 was $6 \mathrm{hrs}$ and $2 \mathrm{~min}$, while the same interval of time in 150 similar patients kept as controls was $2 \mathrm{hrs}$ and $18 \mathrm{~min}$. Amongst the first series there were 32 patients who did not require postoperative sedation at all, while in the second series there were only eight such patients. The difference is indeed striking and requires no further comment.

The pharmacological actıons as they appeared durng this series were indeed encouraging.

The dosage varied from $10 \mathrm{mg}$. to a maximum of $30 \mathrm{mg}$. intravenously, but the drug had to be diluted before administration or irritation of the vein developed. The full onset of action appeared to be slow over a period of 10 to 15 min. at least. The effect lasted several hours. During this time the patient, if under anaesthesia, appeared pale, dry, warm, with quiet even respirations. The eyes were fixed in central position; the pupils were in intense myosis. The absence of any one of the signs mentioned meant that the anaesthetic was not well balanced and that the patient might move or groan suddenly. We found that provided the pupll was in extreme myosis, all was well, but the slightest widening meant that more levomepromazine was required. The amount of added anaesthetuc necessary to maintain a smooth and adequate operative condition was small, and the patient responded within minutes of the discontinuation. 
Under levomepromazine the heart rate was slow within normal range. The pulse was regular and full, the blood pressure drop was around 15 per cent. Often subsequent small doses did not cause' any drop.

The respiratory rate was 16 to 24 per minute, with normal depth. No untoward effects were noticed in two patients known to be mild asthmatics.

Levomepromazine in the dosage ușed caused a good degree of sedation, depression of reflexes, and a moderate amount of relaxation, probably of extrapyramidal origin. Under these conditions clinical potentiation of anaesthetıcs and analgesics was the logical consequence. When the anaesthetic was discontinued and the patient returned to the ward, the drug mamtamed the patient in a condition of apathy and disinterest toward the environment wath a certain amount of separation from pain as shown by the delayed need for postoperative analgesia, and there was no vomiting.

The action on the vegetative system was definite, but not clear cut The pupils were constricted, the mucosae and the skin dry and pale, the blood pressure lowered with a tendency to bradycardia.

\section{SUMmary}

Levomepromazme, R P. 7044, was evaluated in a series of 150 patients undergoing anaesthesia and the pharmacological actions were exammed as they appeared to the anaesthetist in the operating room. Levomepromazine was found to be a very useful drug both during anaesthesia and postoperatively, because it decreased significantly the amount of both the anaesthetic and the postoperative analgesic drug needed

\section{RÉSUMÉ}

La lévomépromazıne, $7044 \mathrm{R} \mathrm{P}$, a été évaluée chez un groupe de 150 patients soumis à l'anesthésie et son activité pharmacodynamıque a été étudiée par l'anesthésiste dans la salle d'operation. La lévomépromazine s'est avérée une drogue très utile au cours de l'anesthésie et également dans la période postopératorre, parce qu'elle permet de dımınuer de façon sıgnificative les besoins en anesthésique et en analgésique post-opératoire

\section{REFERENCES}

1. Sigwald, J, Henne, M, Bouttier, D, Raymondeaud, Cl, \& Quetin, A Activité d'une nouvelle phenothiazıne en psychiatrie et en neurologie Presse méd 872011 (1956)

2. Courvoister, S, Ducrot, R, Fournel, J \& Julou, L Propriétés Pharmaco-dynamiques

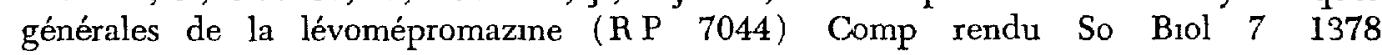
(1958)

3 Courvorsier, $\mathrm{S}$, et al Nouveaux aspects expérımentaux de l'actıvité central des dérivés de la phenothiazıne.- Congr. Méd ahénistes et neuıol Lyon, Sept, 1957

4 Faure, F, Faure, M L, Fournier, M \& Eppe, J. P Sur quelques essais d'application du 7044 R P. dans un pavillon d'enfants deficients. Ann. médico-psychol 2. 500 (1957).

5. Deschamps, A., \& Madre, J Traitements en psychratrie par un nouveau neuroleptique (7044 R P ) Presse méd 651071 (1957)

6 La Rue, L., \& Gosselin, .J Y Usage d'une nouvelle phenothrazıne. Laval méd 2643 (1958).

7. Deschamps, A, \& MADRE, J Résultat d'un nouveau neuroleptıque (lévomépromazıne 7044 R P ) dans les cas de démence précoce grave. Présse méd. 66. 196 (1958). 